\title{
Migrant Entrepreneurship
}


This page intentionally left blank 


\section{Migrant Entrepreneurship: Emerging Themes and Interpretations with Insights from Italy}

BY

PROF. DANIELA BOLZANI

University of Bologna, Italy

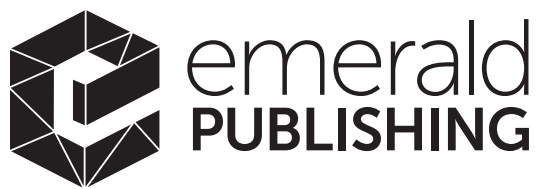


Emerald Publishing Limited

Howard House, Wagon Lane, Bingley BD16 1WA, UK

First edition 2021

(C) 2021 by Emerald Publishing Limited

\section{Reprints and permissions service}

Contact: permissions@emeraldinsight.com

No part of this book may be reproduced, stored in a retrieval system, transmitted in any form or by any means electronic, mechanical, photocopying, recording or otherwise without either the prior written permission of the publisher or a licence permitting restricted copying issued in the UK by The Copyright Licensing Agency and in the USA by The Copyright Clearance Center. Any opinions expressed in the chapters are those of the authors. Whilst Emerald makes every effort to ensure the quality and accuracy of its content, Emerald makes no representation implied or otherwise, as to the chapters' suitability and application and disclaims any warranties, express or implied, to their use.

British Library Cataloguing in Publication Data

A catalogue record for this book is available from the British Library

ISBN: 978-1-83867-492-2 (Print)

ISBN: 978-1-83867-491-5 (Online)

ISBN: 978-1-83867-493-9 (Epub)

ISOQAR certified

Management System,

awarded to Emerald

for adherence to

Environmental

standard

ISOQAR

ISO 14001:2004. 


\section{Table of Contents}

Introduction

Chapter 1 Thirty Years of Studies on Migrant Entrepreneurship: New Opportunities for Management Scholars

Chapter 2 The Role of Firm-level Resources for Migrant Entrepreneurs: New Research Suggestions from Management Theories

Chapter 3 Contextualizing Migrant Entrepreneurship: A Look at Entrepreneurial Ecosystems

Chapter 4 Comparing Internationalization Patterns of Migrant and Non-migrant Entrepreneurs in New Technologybased Firms

Chapter 5 Returnee Entrepreneurship: Insights from an Assisted Voluntary Return Program

Conclusion

Index 
This page intentionally left blank 


\section{About the Author}

Daniela Bolzani is currently a Senior Assistant Professor in Management at the University of Bologna.

She received her PhD in General Management from the University of Bologna in 2013 with the dissertation Internationalization intentions: Micro-foundations and psychological distance perceptions in immigrant and non-immigrant entrepreneurs. Between 2013 and 2017, she worked as a post-doctoral fellow in the Department of Management and the Department of Education Studies at the University of Bologna. Between 2017 and 2020, she worked as an Assistant Professor in Management at the Università Cattolica del Sacro Cuore in Milan (Italy).

She has been a visiting scholar at the Leeds School of Business, the University of Colorado Boulder - USA (2013, invited by Prof. M.D. Foo), and at HEC Paris France (2016, invited by Prof. T. Åstebro).

She has been a member of research teams for several European projects in the domain of entrepreneurship and technology transfer, such as the project "TASTE - Taking Stock of External Engagements of Academics" (PI R. Fini, funded by EU FP7, People - Marie Curie), "SOCCES - SOCial Competences, Entrepreneurship and Sense of initiative" (PI E. Luppi for University of Bologna, funded by EU Erasmus+), and "PROGRESS-TT - PROs GRowing Europe through best practice Solutions for Technology Transfer" (PI F. Munari for the University of Bologna, funded by EU Horizon 2020). In the domain of migration and intercultural issues, she participated to the project "EUMENTORSTEM Creation of a EUropean e-platform of MENTORing and coaching for promoting migrant women in Science, Technology, Engineering and Mathematics" (PI R. Grimaldi for the University of Bologna, funded by EU Erasmus+), and the project "MERGING" (PI S. Ferriani for the University of Bologna, funded by H2020), and Principal Investigator for the project "WeLearn - Intercultural Communication and neighbourness learning" (for the Università Cattolica del Sacro Cuore, funded by EU Erasmus+), and "MIG.EN.CUBE - Fostering MIGrant ENtrepreneurship inCUBation in Europe" (for the University of Bologna, funded by EU Erasmus+). 
Before starting her $\mathrm{PhD}$, Daniela worked as a professional for over five years in the fields of financial audit and international development in Europe and Africa.

Her research interests concern the multi-level antecedents and processes of entrepreneurship, especially in the contexts of international, academic, social, and immigrant business. Because of the different perspectives required to analyze these topics, she favors interdisciplinary approaches and has gained experience in using both quantitative and qualitative research methodologies. 